\title{
Effects of Irradiance Level on the Growth and Photosynthesis of Salvia
}

\author{
Yasuhiko Koike
}

\begin{abstract}
Seedlings of Salvia coccinea, S. splendens and $S$. viridis were grown at $100,50,25$ and $5 \%$ of full sunlight level to determine the influence of irradiance level on their grown and photosynthesis. For all species the shoot length and dry weight of wholeplant were decreased at $25 \%$ sunlight, but there was little defference in them between at 50 and $100 \%$ sunlight. Total leaf area tended to increase at $50 \%$ sunlight in $S$. splendens and $S$. viridis and to decrease at $25 \%$ sunlight in S.coccinea. Leaf area ratio increased with decreasing light intensity in every species, and the degree of increase was the least in S.coccinea. With decreasing light intensity, leaves became thinner and the specific leaf weight decreased for all species. Chlorophyll content and photosynthetic rate more decreased at $25 \%$ than those at 100 and $50 \%$ sunlight in $S$. splendens and $S$. viridis. There were little differences both in the chlorophyll content and photosynthesis among these light intensities in S.coccinea. This indicates that S.coccinea has higher adaptability to low irradiance than other two species. Under weak light condition the stomatal conductance increased for all species. At 5\% sunlight, the plant dry weight was less than about $90 \%$ of that of $100 \%$ sunlight and photosynthetic rate almost decreased to the light compensation point.
\end{abstract}

Index Terms-Irradiance level, photosynthesis, Salvia.

\section{INTRODUCTION}

Salvia are members of the mint family, Lamiaceae, and comprise the largest genus in that family [1]. The fragrant foliage of many salvias has been used for more than 20 centuries. More than 900 species of Salvia exist worldwide. Add to that number both cultivated hybrids and natural hybrids from the wild as well as gardens, and the total figure increases by several hundred or more. Selected cultivars also raise the total significantly.

Salvia coccinea Jussieu ex Murray, widely distributed throughout tropical South America. S. coccinea is commonly called tropical sage. S. coccinea is a plant that adds sparkle to a herbaceous border in all climate zones. More plants grouped with late blooming annuals or perennials make a fine combination. Salvia splendens Roemer \& Schltes is found in the wild only in Brazil at altitudes of 2000-3000m where it is warm year-round. At that time plants were easily grown from seed and kept in greenhouses where they flowered freely for a long period. Salvia viridis, Linnaeus is an erect herbaceous annual occurring in the wild in a region extending from the Mediterranean. S.viridis is known as S.horminum for many years. It's a delightful plant for the front of a summer border, growing $30-60 \mathrm{~cm}$ tall and $30 \mathrm{~cm}$ wide. It is an annual that

Manuscript received March 25, 2013; revised May 24, 2013.

Y. Koike is with the Faculty of Agriculture, Tokyo University of Agriculture, Atsugi, Kanagawa, Japan (e-mail: koike@ nodai.ac.jp). develops rapidly and has a long period of bloom that lasts over a month.

Solar radiation greatly affects the plant growth and productivity through influencing the photosynthesis. Plants adapt to change of iradiance level by modifying their morphology and physiological function so that the available light energy is utilized most efficiently. The effect of light intensity on the grown, leaf anatomy and photosynthesis were reported on Dracaena sanderana [2] and wax begonia [3]. In bedding plants and Cyclamen persicum, Growth and flowering have a great effect in light conditions [4], [5].

However, little is known about the growth responses and physiogical function to different irradiance level in laminaceae annuals. Salvia has been raised in the warm climate area of Japan. This flower crop sometimes suffers from leaf sunburn during hot summer probably because of high irradiance and temperature. In this study, the shoot growth, leaf anatomy and photosynthetic rate under different shade conditions were investigated for seedlings of $S$. coccinea, S.splendens and S.viridis. This information on growth response and acclimation features to the change of light intensity are useful for improving the raising system.

\section{MATERIALS AND METHODS}

On Apr.1, 2002, seeds were sowed into sand put in 0.5-L polyethylene pots. These pots were placed at $30 / 25^{\circ} \mathrm{C}$ room for germination. Both plants of seeds were purchased from the store. On Apr., 25, uniform seedlings were selected and transplanted into 1.2-L plastic pots filled with sand and loam $(1: 1, \mathrm{v} / \mathrm{v})$. After 2 weeks, these plants were subjected to four kinds of light levels by placing them in plastic frames surrounded by one to several layers of black shade cloth: $100 \%, 50 \%, 25 \%$ and $5 \%$ of full sunlight (Table I). 10 plants were used in each treatment.

Just before the strat of treatment, the uppermost unfold leaf was tagged with a label. On May 2, the chlorophyll content of the tagged leaf was determined with Green Meter (Fuji Co., Ltd., GM1) and expressed as relative value value. The photosynthetic rate $(\mathrm{Pn})$, stomatal conductanceb to $\mathrm{CO}_{2}$ transfer (Gs) and transpiration rate (E) of the leaf area tagged leaf were measured a portable

Photosynthesis sytem (LI6400; LI-COR, Inc.). On May 26, the shoot length was measured and the total leaf area was determined with an area meter (LI3000; LI-COR, Inc.). Thereafter, all plants were removed from the pots and divied into leaves, stems and roots. They were then oven dried at $80^{\circ} \mathrm{C}$ for $48 \mathrm{hrs}$ and their dry weights were measured. The top -root ratio and leaf area ratio (LAR) was calculated as leaf + stem dry weights/root dry weight and as total leaf area/dry 
weight of whole plant, respectively.

\begin{tabular}{cccc} 
TABLE I: IRRADIANCE LEVELS ON A CLEAR DAY OF TREATMENTS \\
$\begin{array}{c}\text { Treatment } \\
\text { (sunlight levels) }\end{array}$ & $\begin{array}{c}\text { PPFD } \\
\left(\mu \mathrm{molm}^{-2} \mathrm{~s}^{-1}\right)\end{array}$ \\
\hline $100 \%$ & 1200 & - & 1800 \\
$50 \%$ & 650 & - & 800 \\
$25 \%$ & 250 & - & 350 \\
$5 \%$ & & $<$ & 85 \\
\hline
\end{tabular}

After the leaf area was determined, a leaf disk $\left(1 \mathrm{~cm}^{2}\right)$ was removed from the tagged leaf with a razor blade and immediately weighed to determine the specific leaf weight (SLW). The disk was then fixed in FAA solution. The leaf tissue was dehydrated and embedded in paraffin and sectioned $(10 \mu \mathrm{m})$ for measuring the leaf thickness under light microscope.

The experiment was conducted with a completely randomized design. The results of all variables were subjected to analysis of variance. Significance of linear and quadratic models were determined with percent sunlight as the independent variables.

\section{RESULTS}

In S.coccinea and S.viridis, shoot length decreased with increase in shade level, but that of S.splendens was decreased greatly only at $5 \%$ sunlight (Table II). Plant dry weight reduced at $25 \%$ and further decreased at $5 \%$ for both species. There was little difference in shoot length and plant dry weight between $100 \%$ and $50 \%$. With decreasing light intensity, the top-root ratio tended to decrease in S.coccinea but to increase in S.splendens. The LAR increased with decreaseing light level for all species. S.splendens and S.viridis increased the LAR more than S.coccinea under heavy shade conditions. The leaf thickness and SLW decreased with increasing the shade level for both species. The degree of reduction in SLW was greater in S.splendens and S.viridis than S.coccinea.
Shade treatments had little effect on the chlorophyll content in sunflower. The chlorophyll tened to decrease with decreasing light levels in salvia (Table IV).

Photosynthetic rate $(\mathrm{Pn})$, stomatal conductance to $\mathrm{CO}_{2}$ transfer (Gs) and transpiration rate (E) in leaves grown under different irradiance levels are shown in Table V. The effect of light intensity on Pn was smaller in sunflower than salvia. There was little difference in Pn among 100\%, 50\% and 25\% sunlight in sunflower. The Pn decreased at 50\% sunlight in salvia. At 5\% sunlight the photosynthesis almost reached to the light compensation point in both species. Gs was greater at $50 \%$ and $25 \%$ sunlight in salvia. In sunflower, Gs became greater with decreasing irradiance levels. The Gs was the least at $100 \%$ sunlight for both species. In both species, E was little affected.

\section{DISCUSSION}

Hevy shade decreases the shoot growth in some kinds of plants. The dry weight of some bedding plants decreased by $50 \%$ at about $30 \%$ irradiance level [6]. In Cyclamen persicum dry weights of leaves and stems under $80 \%$ shade level were $60 \%$ of those under full sunlight [5]. In this study, shoot extension and plant dry weight were substantially suppressed under lower than $25 \%$ of full sunlight in both species. In chrysanthemum, however, shoot growth was little affected at $24 \%$ of full sunlight [4]. Growth response of Laminacea seedling seems to be more sensitive to the change of light conditions than chrysanthemum. This study indicates that higher than $50 \%$ sunlight level is change. Both shoot length and leaf area decreased with decreasing light levels. Total leaf area was extremely decreased at $5 \%$ in every species (Table III). In S.splendens and S.viridis, the leaf area tened to increase $50 \%$. At $25 \%$ the area decreased in S.coccinea. The LAR required for the normal growth of seedlings in these species.

TABLE II: EFFect of IRRADiance LeVel on the Shout ENGTH, Plant Dry Weight AND Top-Root Ratio of S. COCCINEA, S. SPLENDENS AND S. VIRIDIS.

\begin{tabular}{|c|c|c|c|c|c|}
\hline \multirow{2}{*}{ variables } & \multicolumn{4}{|c|}{ treatment (sunlight level) } & \multirow{2}{*}{ Regression $^{2}$} \\
\hline & $100 \%$ & $50 \%$ & $25 \%$ & $5 \%$ & \\
\hline \multicolumn{6}{|c|}{ S.coccinea } \\
\hline \multirow[t]{2}{*}{ Shoot length $(\mathrm{cm})$} & 28.3 & 26.1 & 20.1 & 11.2 & $L^{* *} \mathrm{r}^{2}=0.39$ \\
\hline & & & & & $Q^{* *} \mathrm{r}^{2}=0.86$ \\
\hline \multirow[t]{2}{*}{ Plant dry weight $(\mathrm{g})$} & 5.1 & 5.9 & 2.1 & 1.3 & $L^{* *} \mathrm{r}^{2}=0.51$ \\
\hline & & & & & $Q^{* *} \mathrm{r}^{2}=0.81$ \\
\hline \multirow{2}{*}{ Top-root ratio } & 3.7 & 3.6 & 3.3 & 2.5 & $L^{* *} \mathrm{r}^{2}=0.41$ \\
\hline & & & & & $Q^{* *} \mathrm{r}^{2}=0.52$ \\
\hline \multicolumn{6}{|c|}{ S.splendens } \\
\hline Shoot length $(\mathrm{cm})$ & 21.6 & 20.1 & 12.8 & 4.8 & $L, Q^{\text {ns }}$ \\
\hline \multirow[t]{2}{*}{ Plant dry weight(g) } & 6.1 & 4.9 & 1.9 & 0.6 & $L^{* *} \mathrm{r}^{2}=0.62$ \\
\hline & & & & & $Q^{* *} \mathrm{r}^{2}=0.81$ \\
\hline \multirow[t]{2}{*}{ Top-root ratio } & 3.2 & 2.8 & 4.2 & 3.5 & $L^{*} \mathrm{r}^{2}=0.5$ \\
\hline & & virid & & & \\
\hline \multirow[t]{2}{*}{ Shoot length $(\mathrm{cm})$} & 18.7 & 22.1 & 13.1 & 5.8 & $L^{* *} \mathrm{r}^{2}=0.32$ \\
\hline & & & & & $Q^{* *} \mathrm{r}^{2}=0.83$ \\
\hline \multirow[t]{2}{*}{ Plant dry weight(g) } & 4.6 & 5.1 & 1.1 & 0.8 & $L^{* *} \mathrm{r}^{2}=0.66$ \\
\hline & & & & 0.7 & $Q^{* *} \mathrm{r}^{2}=0.81$ \\
\hline Top-root ratio & 2.9 & 3.2 & 3.7 & 2.1 & $L, Q^{\mathrm{ns}}$ \\
\hline
\end{tabular}

${ }^{\mathrm{z}} L, Q$ : Linear and quadratic regression, respectinely. ${ }^{* * * *}: P<0.05$ and 0.01 , respectly. ${ }^{\text {ns }}$ : not significant. 


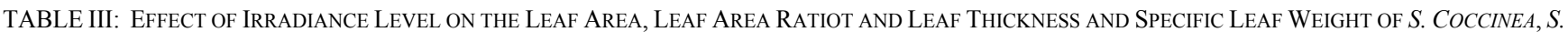
SPLENDENS AND S. VIRIDIS

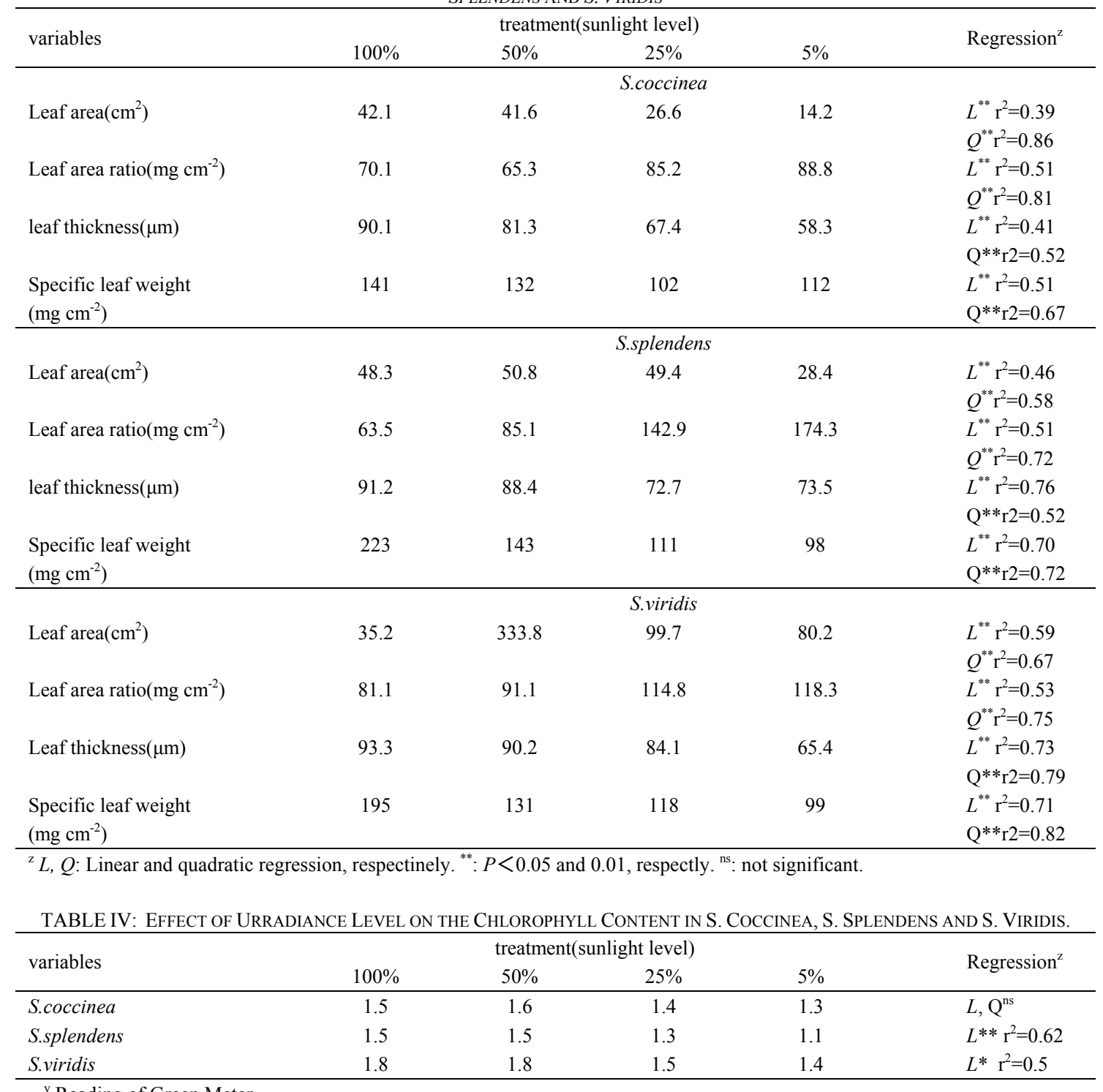

${ }^{\mathrm{y}}$ Reading of Green Meter.

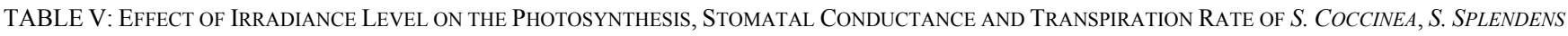

\begin{tabular}{|c|c|c|c|c|c|}
\hline \multirow{3}{*}{ variables } & \multirow{2}{*}{\multicolumn{4}{|c|}{ treatment(sunlight level) }} & \multirow{3}{*}{ Regression $^{\mathrm{z}}$} \\
\hline & & & & & \\
\hline & $100 \%$ & $50 \%$ & $25 \%$ & $5 \%$ & \\
\hline \multicolumn{6}{|c|}{ S.coccinea } \\
\hline $\begin{array}{l}\text { Photosynthetic rate } \\
\qquad\left(\mu \mathrm{mo} 1 \mathrm{~m}^{-2} \mathrm{~s}^{-1}\right)\end{array}$ & 3.9 & 4.1 & 4.8 & 0.4 & $Q^{* *} \mathrm{r}^{2}=0.51$ \\
\hline Stomatal conductance & 0.2 & 0.2 & 0.3 & 0.3 & $L * * \mathrm{r}^{2}=0.71$ \\
\hline$\left(\mathrm{mo} \mathrm{l} \mathrm{m} \mathrm{m}^{-2} \mathrm{~s}^{-1}\right)$ & & & & & $Q^{* * r^{2}=0.73}$ \\
\hline Transpiration rate & 3.6 & 3.4 & 3.6 & 3.6 & $L, Q^{\mathrm{ns}}$ \\
\hline$\left(\mathrm{mmo} \mathrm{l} \mathrm{m}^{-2} \mathrm{~s}^{-1}\right)$ & & & & & \\
\hline \multicolumn{6}{|c|}{ S.splendens } \\
\hline Photosynthetic rate & 11.3 & 9.74 & 6.45 & 0.3 & $L * * \mathrm{r}^{2}=0.68$ \\
\hline$\left(\mu \mathrm{mo} 1 \mathrm{~m}^{-2} \mathrm{~s}^{-1}\right)$ & & & & & $Q^{* * r^{2}=0.91}$ \\
\hline Stomatal conductance & 0.2 & 0.3 & 0.4 & 0.2 & $Q^{* *} \mathrm{r}^{2}=0.51$ \\
\hline$\left(\mathrm{mo} \mathrm{l} \mathrm{m}^{-2} \mathrm{~s}^{-1}\right)$ & & & & & \\
\hline \multirow{3}{*}{$\begin{array}{l}\text { Transpiration rate } \\
\qquad\left(\mathrm{mmo} 1 \mathrm{~m}^{-2} \mathrm{~s}^{-1}\right)\end{array}$} & 4.1 & 3.8 & 3.9 & 3.6 & $L, Q^{\mathrm{ns}}$ \\
\hline & & & & & \\
\hline & \multicolumn{5}{|c|}{ S.viridis } \\
\hline Photosynthetic rate & 8.9 & 8.7 & 6.1 & -0.5 & $L * * \mathrm{r}^{2}=0.49$ \\
\hline$\left(\mu \mathrm{mo} 1 \mathrm{~m}^{-2} \mathrm{~s}^{-1}\right)$ & & & & & $Q^{* *} \mathrm{r}^{2}=0.86$ \\
\hline Stomatal conductance & 0.2 & 0.3 & 0.4 & 0.12 & $Q^{* *} \mathrm{r}^{2}=0.51$ \\
\hline$\left(\mathrm{mo} \mathrm{l} \mathrm{m} \mathrm{m}^{-2} \mathrm{~s}^{-1}\right)$ & & & & & \\
\hline Transpiration rate & 3.7 & 3.8 & 3.8 & 3.6 & $L, Q^{\mathrm{ns}}$ \\
\hline$\left(\mathrm{mmo} 1 \mathrm{~m}^{-2} \mathrm{~s}^{-1}\right)$ & & & & & \\
\hline
\end{tabular}

${ }^{\mathrm{z}} L, Q$ : Linear and quadratic regression, respectinely. ${ }^{* *}: P<0.05$ and 0.01 , respectly. ${ }^{\text {ns }}$ : not significant. 
Bedding plants growth under shade condition change their form to adapt the low irradiance. In Achillea, shoot extension increased with decreasing light intensity at the sacrifice of leaf area development [4]. On the other hand, Coleus [7] and marigold [6] increased the leaf area. However, Laminaceae seedlings did not show such morphological Heavier shade brought about thinner leaves, with lower SLW for both species. Similar responses were obtained in Dracaena sanderana [2] and Ficus benjamina [8]. The leaf growth under shade conditions has higher chlorophyll content [8], [9]. This is a physiological adaptation to utilize light energy more efficiently. However, the chlorophyll content decreased with increasing shade levels in S. coccinea and was little affected in S.splendens and S.viridis. These do not suggest that Laminaceae seedlings have such an adaptation mechanism.

In chrysanthemum [9], $\mathrm{CO}_{2}$ assimilation rates of the leaf decreased under shade conditions. Photosynthesis decreased by increasing the level of shade in Cyclamen persicum [5]. In this study, the photosynthetic rate decreased greatly at a greatly at a 5\% sunlight level, but the rate at the 50\% level was comparable to that at full sunlight. This indicates that photosynthetic function is not affected if young Laminacea trees are grown under light levels higher than $50 \%$ full sunlight. Under $25 \%$ full sunlight, photosynthesis was a little decreased in S.coccinea, probably because of a reduction of chlorophyll. However, photosynthesis was little affected in S.coccinea. S. splendens and S.viridis seems to have a more effective mechanism to utilize low irradiance compared with S.coccinea.

At $25 \%$ sunlight level, plant dry weights decreased although the photosynthetic rate was not affected in S.coccinea. This indicates that the decrease in leaf growth such as leaf area and thickness brought about the decrease in total photosynthetic production. In S.splendens and S. viridis, the reduction of dry weight caused the reduction of both leaf growth and photosynthetic ability. Under 100\% shade condition, the inhibition of both photosynthesis and leaf growth resulted in a great decrease of dry weight in every species.

Stomatal conductance to $\mathrm{CO}_{2}$ transfer was affected by shade treatments in all species. The conductance was greater in all shade levels than full sunlight. This was different from that obtained in wax begonia which decreased conductance under shade conditions [9]. In chrysanthemum [10], changes in $\mathrm{CO}_{2}$ assimilation were strongly strongly correlated to stomatal conductance to $\mathrm{CO}_{2}$ when leaves were exposed to different irradiance levels. The increase in conductance might prevent the decrease of photosynthetic ability by increasing $\mathrm{CO}_{2}$ flow into leaves in Laminaceae plants grown under shade conditions. Little or a little reduction of $\mathrm{CO}_{2}$ assimilation capacity at $50 \%$ sunlight level seems to be partly caused by greater stomatal conductance. At $5 \%$ sunlight level, such compensation effect disappeared because of the inhibitory effect of low radiance on photosynthesis.

The present results indicate that the growth of Laminacea fruit trees is greatly reduced under heavier shade conditions. These seedlings showed only a little morphological adaptation to the low irradiance level. Increased stomatal conductance and little reduction of chlorophyll content seem to prevent the decrease in photosynthetic ability under shade conditions. The deference in shade tolerance among the three species could not be clarified cleary in this study. However, S.coccinea seems to be more adaptive to shade compared with S.splendens and S.viridis. The effect of irradiance levels on flowering should be studied more to clarify the shade tolerance of these Laminaceae.

\section{REFERENCES}

[1] B. Clebsch, The New Book of Salvias, Cambridge, U.K.: Timber Press, pp. 17-304, 2003.

[2] S. V. Vladimirova, D. B. McConnell, M. E. Kane, and R. W. Henley, "Morpholpgical plasticity of Dracaena sanderana 'Ribbon'in response to four light intensities," HortScience, vol. 32, no.6, pp. 1049-1052, Oct.1997.

[3] I. J. Warrington and R. A. Norton, "An evaluation of plant growth and development under various daily quantum integrals," J. Amer. Soc. Hortic. Sci., vol. 116, no.3, pp. 544-551, Mar. 1991.

[4] B. A. Fausey, R. D. Heins, and A. C. Cameron, "A Daily light integral affects flowering and quality of greenhouse-grown Achillea, Gaura, and Lavandula," HortScience, vol. 40, no.1, pp. 114-118, Jan. 2005.

[5] O. Wook, I. H. Cheon, and E. S. Runkles, "Photosynthetic daily light integral influences flowering time and crop Characteristics of Cyclamenn persicum," HortScience, vol. 344, no. 2, pp. 341-344, Feb. 2009.

[6] J. E. Faust, V. Holcombe, N. C .Rajapakse, and D. R. Layne, "IThe effect of daily light integral on bedding plant growth and flowering," HortScience, vol. 40, no. 3, pp. 645-649, Mar. 2005.

[7] K. F. Garland, S. E. Burnett, L. B. Stack, and D. Zhang, "Minimum daily light integral for growing high-quality coleus," HortTechnology, vol. 20, no. 5, pp. 929-933, Oct. 2010.

[8] B. S. Falis, A. J. Lewis, and J. A. Barden, "Anatomy and morphology of sun- and shade -grown Ficus benjamina," J. Amer. Soc. Hortic. Sci., vol. 107, no. 7, pp. 754-757, July 1982.

[9] K. S. Nemali and M. W. van Iersel, "Acclimation of wax begonia to light intensity: changes in photosynyhesis, respiration, and chlorophyll concentration," J. Amer. Soc. Hortic. Sci., vol. 129, no. 6, pp. 754-751, June 2004

[10] E. J. Holcomb, "Photosynthetic response curves for chrysanthemum grown at different PPF levels," HortScience, vol. 23, no. 4, pp. 206-208, April 2005.

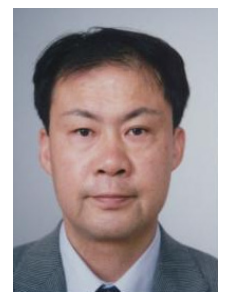

Yasuhiko Koike was born on 8 Aug.1964 in Osaka, Japan. He was graduated from Osaka preffectual University with a BA in 1987 , with a MS in horticulture in 1989, and Tokyo Univ. of Agriculture with a PhD in Agriculture(Tokyo, Japan) in 2006. $\mathrm{He}$ is major in horticulture, especially floriculture.

From 2009, he is a professor of horticulture at Tokyo Univ. of Agriculture, where he focused on regulation of flowering in ornamentals. 